\title{
A Rapid Method for Assessing Rates of Soil Erosion from Rangeland: an Example from Botswana
}

\author{
NICK ABEL AND MICHAEL STOCKING
}

\begin{abstract}
The erosion of rangeland solls is a widespread problem in Africa. Yet, there are few methods for estimating its rate. Using data from 2 catchments in Botswana, a technique for estimating erosion and sediment yield is demonatrated. It involves low level photographic sampling of vegetation cover, kriging to interpolate percentage cover from sample points, and the application of a simplified soil loss estimation procedure called SLEMSA. This modelling approach gives gross soil loss and allows the estimation of sediment yield. It is easy and cheap to apply and gave results in line with field experience.
\end{abstract}

Key Words: Soll erosion, rangeland degradation, rapid rural appraisal, Botswana

Most semiarid regions report rangeland degradation because of heavy grazing (e.g., Pratt and Gwynne 1977; Penning de Vries and Djiteye 1982). Soil erosion is normally cited as a contributory process, but estimates of its rate on rangeland are scarce. This is not, we suggest, because such estimates are considered unimportant, but because technically feasible, cost-effective methods have yet to be developed for rangelands. In contrast, arable lands are relatively well served.

One reason for the lack of development of methods for rangeland and the poor compatability of existing methods for arable areas (e.g. Universal Soil Loss Equation, USLE: Wischmeier and Smith 1978) is the difficulty of estimating and interpreting the most influential variable in soil loss: vegetation cover. The USLE deals with vegetation cover primarily through its 'cropping management factor', C, which is empirically determined. Typically, many values of $\mathrm{C}$ are required for a single crop, each needing years of experi-

\footnotetext{
Authors are respectively rangeland ecologist and soil scientist with the Overseas Development Group, School of Development Studies, University of East Anglia, Norwich NR4 7TJ, United Kingdom.

This paper is a contribution to the work of the Integrated Farming Pilot Project, Botswana, and is funded and supported by the International Livestock Centre for Africa, Ethiopia.

We are grateful for comments received from Y. Biot and $\mathbf{R}$. Webster on a draft of this paper.

Manuscript accepted 13 April 1987.
}

mentation on erosion plots. Index values for $\mathrm{C}$ so derived have no inherently rational meaning other than as a comparative measure integrating a variety of unknown influences: extrapolation is impossible. Furthermore, the USLE is strictly valid only where the factor values for the equation have been experimentally determined, a situation that pertains only to cropland east of the Rocky Mountains in the United States. To extend these factor values to the different soils, climate, and land use of southern Africa is unwise without independent verification. However, the major control of erosion is through the protective cover of vegetation (Stocking and Elwell 1976), which, expressed as a percentage of the ground covered by vegetation, is a rationally explicable variable that can be used from prediction (Elwell and Stocking 1976).

On cropland, cover is fairly easily measured, usually by means of a quadrat sighting frame (Elwell and Gardner 1975). On rangeland, both the large areas involved and the spatial and temporal variability in vegetation cover preclude ground-based measurement and dictate the utilization of some form of remote sensing. Although much effort has gone into assessing ground cover by computer analysis of Landsat and NOAA imagery, initial enthusiasm (Tucker et al. 1983) has not been sustained by subsequent field tests. The accuracy of estimates of grass cover (and biomass) from satellite imagery is reduced by at least the following factors:

* techniques depend on the quantity of green material present, so that estimates are confined to the growing season (Curran 1983). Critically, the dry grass remaining at the end of the dry season for protection against the first rains cannot be assessed;

* it is not known whether sensors can distinguish between the canopies of the woody vegetation and the ground layer (Prince and Astle 1986, Prince and Tucker 1986);

* when vegetation cover is sparse, the background reflectance of the soil can swamp the reflectance of the vegetation, preventing accurate estimation of cover (Curran 1983);

* spatial variation in soils (Richardson and Wiegand 1977) and topography (Curran 1983) can further impair the accuracy of cover estimates;

JOURNAL OF RANGE MANAGEMENT 40(5), September 1987 
* atmospheric absorption and scattering of radiation can cause nonsystematic biases (Short 1982), while cloud cover at crucial times can prevent sensing of the ground.

The usefulness of satellite imagery is further reduced by its inability to record numbers of livestock or wildlife using the range. Since these are the primary agents of rangeland change, estimating their numbers and distribution is crucial to the interpretation of degradation.

Criteria for the selection of a method for assessing rates of soil erosion can therefore be derived. First, since only land of low intrinsic value is concerned, the method must be cheap and suited to the survey of extensive areas. Secondly, it should be able to assess the cover of the ground layer with acceptable precision and accuracy, do this whether the vegetation is green or dry, and be able to distinguish between woody and herbaceous cover. Thirdly, the method should be able to assess the distribution and number of rangeland animals. Finally, it should incorporate a soil loss model which can be adapted to a variety of environmental conditions, and which makes modest demands for data. Such an approach should be especially suitable for the urgent problems of rangelands in developing countries where skills and funds are scarce.

This paper describes an attempt in southeast Botswana to meet our own criteria for a satisfactory rangeland soil loss model. Three main objectives are specified: first, to describe a rapid method for mapping ground layer vegetation cover; secondly, to demonstrate the use of an appropriate soil loss model; thirdly, to estimate gross field rates of soil loss and sediment yields (net loss) for 2 contrasting areas in southeast Botswana.

\section{The Study Area}

This work is a contribution to the studies of 'traditional' agropastoral production (mixed farming) in southeast Botswana by the Integrated Farming Pilot Project (IFPP) and the International Livestock Centre for Africa. The IFPP study area (Fig. 1) receives around $520 \mathrm{~mm}$ mean annual rainfall (Vossen et al. 1985), falling mainly between October and May. It occupies about $700 \mathrm{~km}^{2}$ over

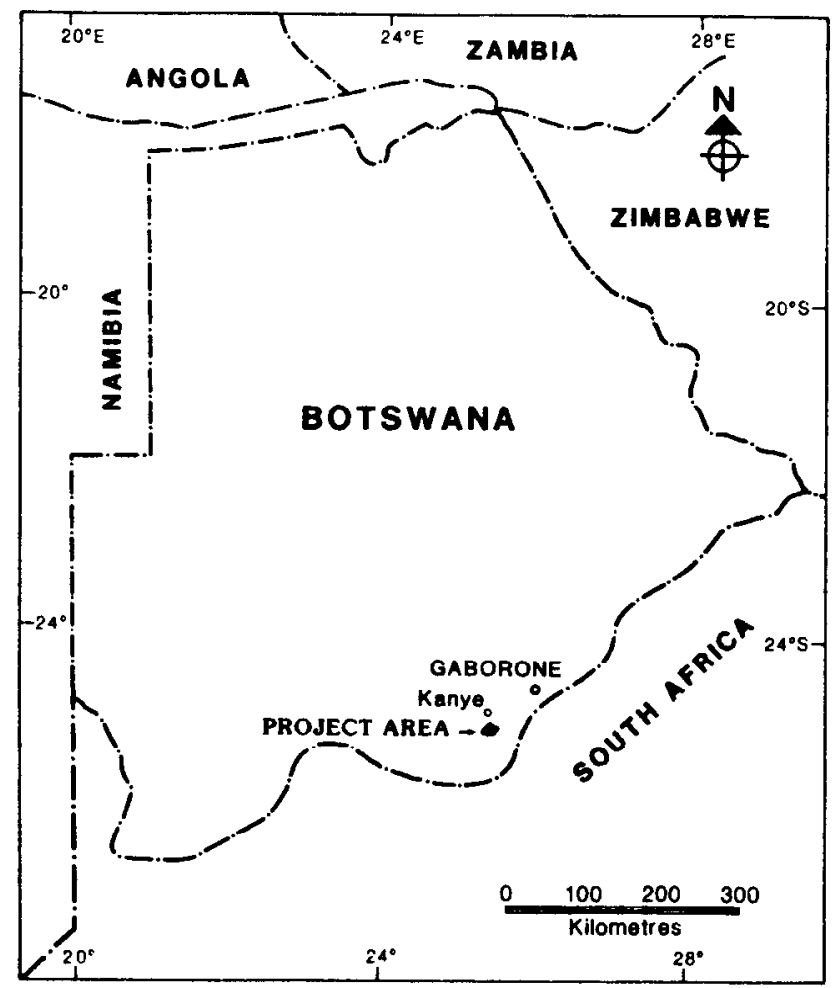

Fig. 1. Location of the study area in southern Africa.

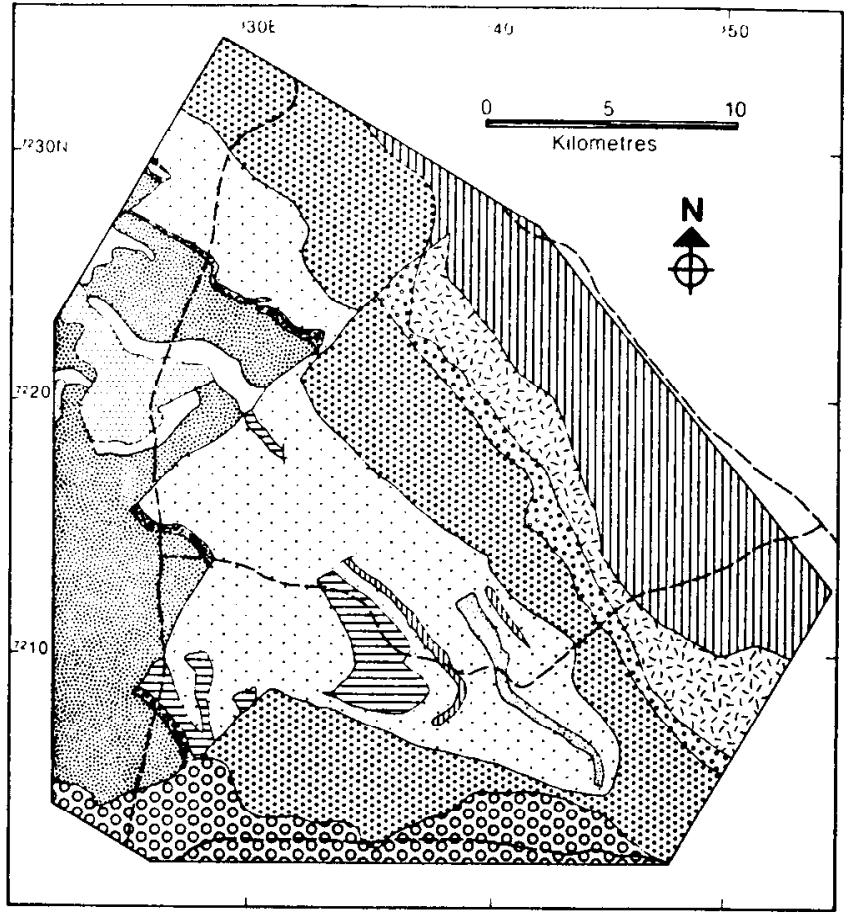

Key: Groundwater potential (after Sekwale, 1983)

1 - poor. $0-3 \mathrm{~m}^{3} / \mathrm{hr}$ borehole yield

2 - poor 10 fair, $3-7 \mathrm{~m}^{3} / \mathrm{hr}$ borehole yield

3 - good, $>10 \mathrm{~m}^{3} / \mathrm{hr}$ borehole yield
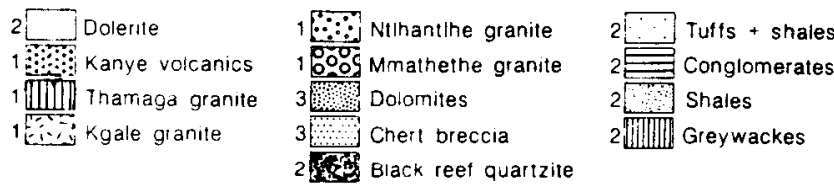

Source. from Tombale (in press)

Fig. 2. Geology of the study area.

Karoo sedimentary rocks with volcanic intrusions (Fig. 2). The soils derived from the Kanye volcanics (felsite) are loamy sands and sandy loams, often shallow with much exposed rock (Eutric Regosols in the FAO/UNESCO Soil Legend). The granites underlie a sandy loam (again, a Eutric Regosol but merging into Ferric and Chromic Luvisols where deeper). The dolomite plain to the west carries a fine sandy loam over a shallow calcrete pan (Calcaric Regosol). Soils over tuffs and shales vary in texture from sandy loam to clay, and in depth.

This study confines itself to rangeland with less than $20 \%$ canopy cover of woody vegetation so that we concentrated on grass cover and kept within the experimental conditions of the SLEMSA soil loss model. This limited us to rangeland on the northeastern granite, where we chose the Moreane $\left(65 \mathrm{~km}^{2}\right)$ and the Kamawe $(21.5$ $\mathrm{km}^{2}$ ) catchments, and the western dolomite plain (Fig. 2) from which no streams drain.

\section{Methods}

\section{Estimates of Grass Cover}

For convenience we refer to 'grass cover' as the proportion of the ground covered by the aerial parts of grasses and forbs in vertical projection. As the key variable in soil loss, it was estimated from aerial photographs and mapped by "kriging". The method is described in Dancy et al. (1986) and is given here only in summary.

Systematic low-level aerial surveys on transects $1.6 \mathrm{~km}$ apart were used for visual assessments of the distribution and abundance of livestock. A 35-mm camera with 55-mm lens mounted in the 
fuselage of the Cessna $\mathrm{C} 150$ aircraft took vertical sample photographs at 25 -second intervals. With the plane flying at $144 \mathrm{~km} / \mathrm{hr}$ in still air, a sample photograph would therefore be taken each kilometre. In practice, head, tail, and crosswind components affected the sampling distance and the accuracy of the flightlines. Detailed navigational notes were therefore kept in order to locate the actual tracks flown (Fig. 3). By flying at $120 \mathrm{~m}$ each exposure covered $60 \mathrm{~m} \times 90 \mathrm{~m}$.

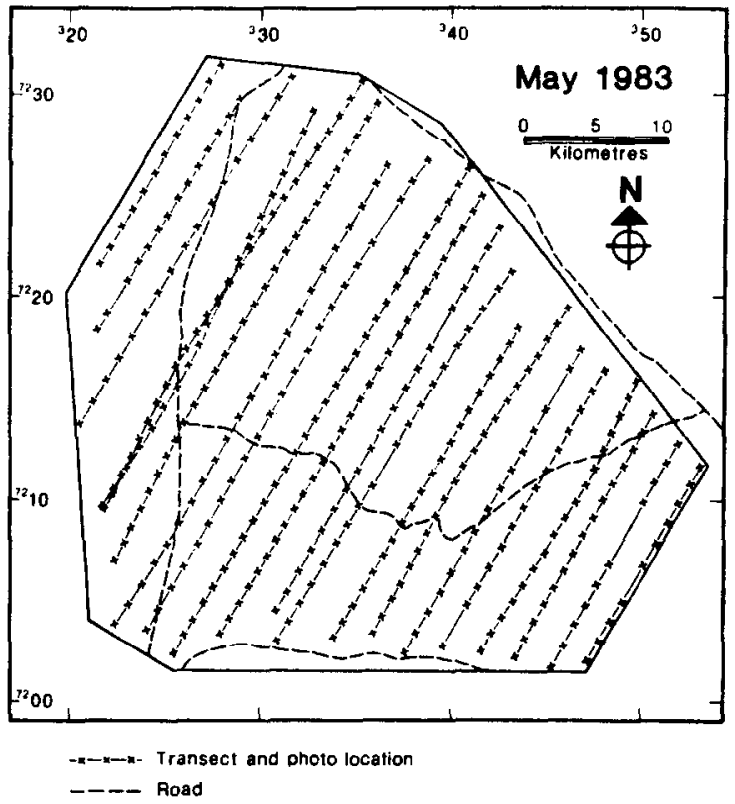

Fig. 3. Location of transects and aerial photographs.

After film processing, the colour diapositive slides were projected and subjective estimates made of grass cover. These were validated on the ground from 51 plots on which cover had been measured by step-point transects (Evans and Love 1957) and for which directly comparable aerial photographs had been taken. Comparisons of subjective estimates and measured results (Fig. 4)

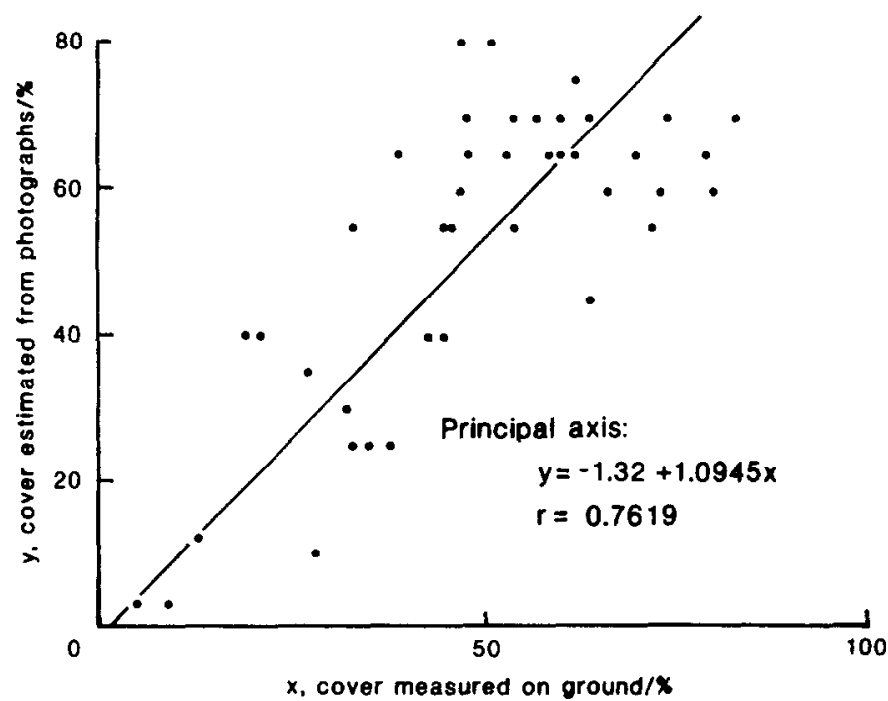

Fig. 4. Comparison of estimates of vegetation cover percentage from aerial photographs against ground measurements.

showed reasonable correspondence and little influence of bush on estimates of grass cover. Our subjective assessments of cover are sufficiently precise and accurate to serve as the samples for "kriging".

\section{Mapping of Grass Cover: Kriging}

Estimates of grass cover for the soil loss model were to be needed for each $1-\mathrm{km}^{2}$ cell, but our sampling rate was only 1 photograph per $2 \mathrm{~km}^{2}$, and these were irregularly located, giving many cells none and a few several estimates of grass cover. Kriging, a procedure by which intermediate values can be estimated from a coarse and irregular sampling pattern to a fine and regular grid, seemed ideal for our requirements.

The stages of kriging are: the description and modelling of spatial relationships between samples; estimation from sample points to a fine grid; and construction of an isoline map (Webster 1985). These steps are discussed briefly.

The closer 2 points are in space, the more likely they are to be similar. Conventional statistical methods, which ignore this relationship, result in over-estimates of the variation in spatially autocorrelated data. Kriging, by contrast, exploits spatial autocorrelation to improve precision.

The relationship between spatial separation of points and variation between them can be quantified and modelled in terms of their semivariance and lag. The semivariance of 2 points is half the squared difference between the values at the 2 points. Lag is the separation between them. A semivariogram is a graph of semivariance against lag. Dancy et al. (1986) describe how a model was fitted to the sample semivariograms constructed for each of the aerial surveys. An isotropic relationship holds when semivariance and lag are the same in all directions on a plane surface, whereas the more common anisotropic state exists where the variation is greater in some directions than others. This influence of direction, revealed by constructing semi-variograms for each of eight $22.5^{\circ}$ sectors, was built into the model semivariogram.

In the next stage, estimation from the sample points to a fine grid, the equation of the model fitted to the semivariogram was used to estimate cover based on the local weighted mean of between 7 and 20 neighbouring sample points. The weights were selected to give an unbiased estimate with minimum variance. In the final step, the SURFACE II graphics system (Sampson 1978) was used to construct isoline maps from the interpolated cover values (Fig. 5). The isoline maps were the source of data on vegetation cover in the soil loss model.

\section{The Soil Loss Model: SLEMSA}

Given a dearth of methods that are practical to apply to poor but rapidly eroding developing countries, Zimbabwe (then Southern Rhodesia) embarked in the late 1960 s on the development of a soil loss model that could provide estimates of annual soil losses through sheet erosion on arable lands. When compared with actual measured rates of soil loss, the Universal Soil Loss Equation had given inconsistent, almost-random predictions (Wendelaar 1978). To improve on the USLE predictions would have required a massive research effort several times the size of the total agricultural research budget (Stocking 1981). The need was, therefore, for a method that combined simplicity and cheapness with reasonable accuracy and the ability to extrapolate to unmeasured conditions and to the complex farming systems of a developing country.

The result was a framework for the development of local soil loss models that takes into account the specific conditions of major agro-ecological zones, their soils and environments. This development of simple local models, denoted by the acronym SLEMSA (Soil Loss Estimation Model for Southern Africa), is described by Elwell and Stocking (1982), and a detailed manual on its application to the Highveld of Zimbabwe is in Elwell (1978). SLEMSA is an approach to soil loss estimation which uses a set of "control variables', the values for which are fairly easily determined and which have some rational physical meaning. These control variables form the input to 3 sub-models, which, when combined, give an estimate of soil loss. The structure of the model is given in Figure 6.

In its Cover (or Crop) Sub-model the SLEMSA framework 

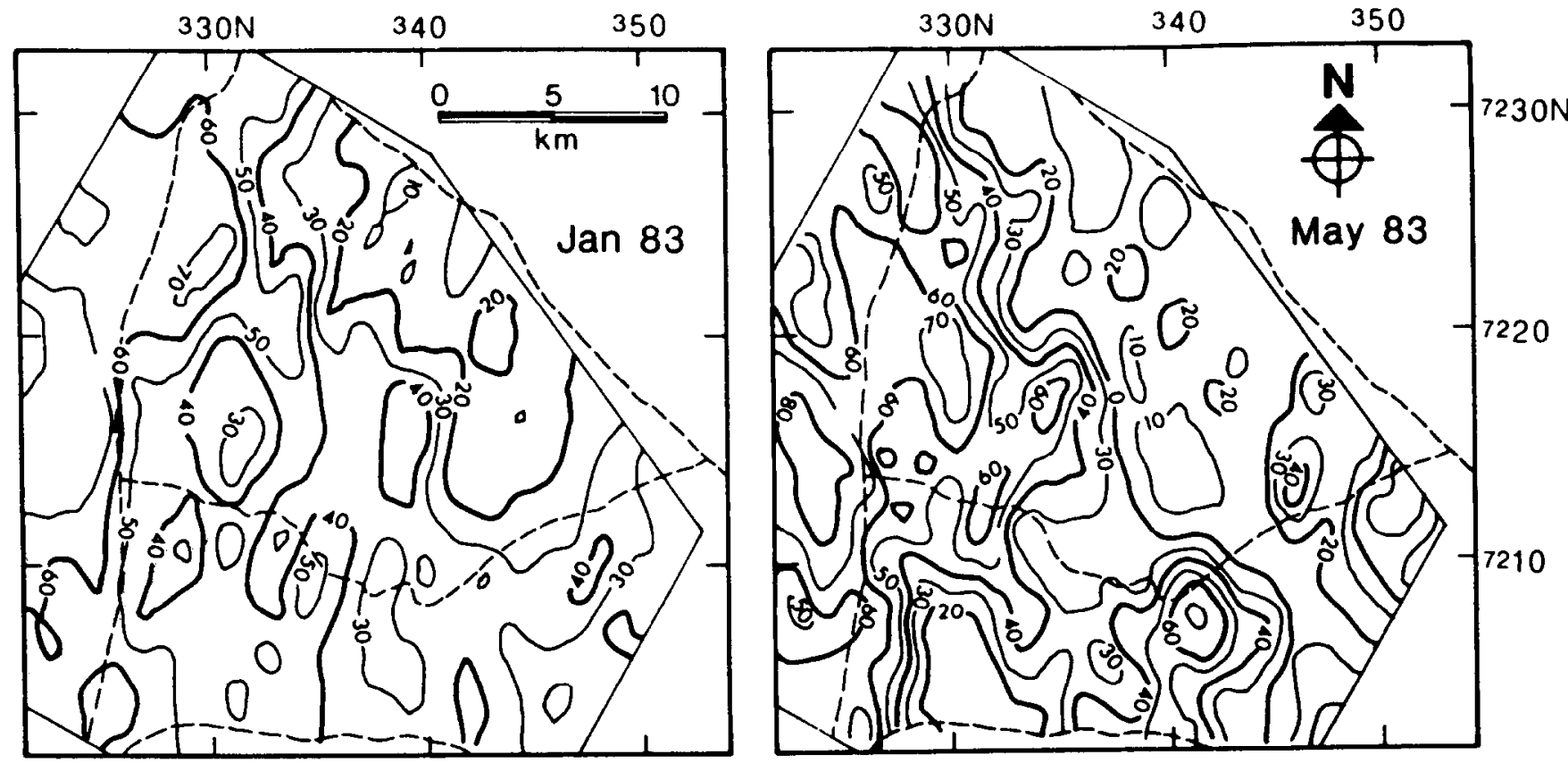

Note: the sampling frequency for Jan 83 was half that for the other months

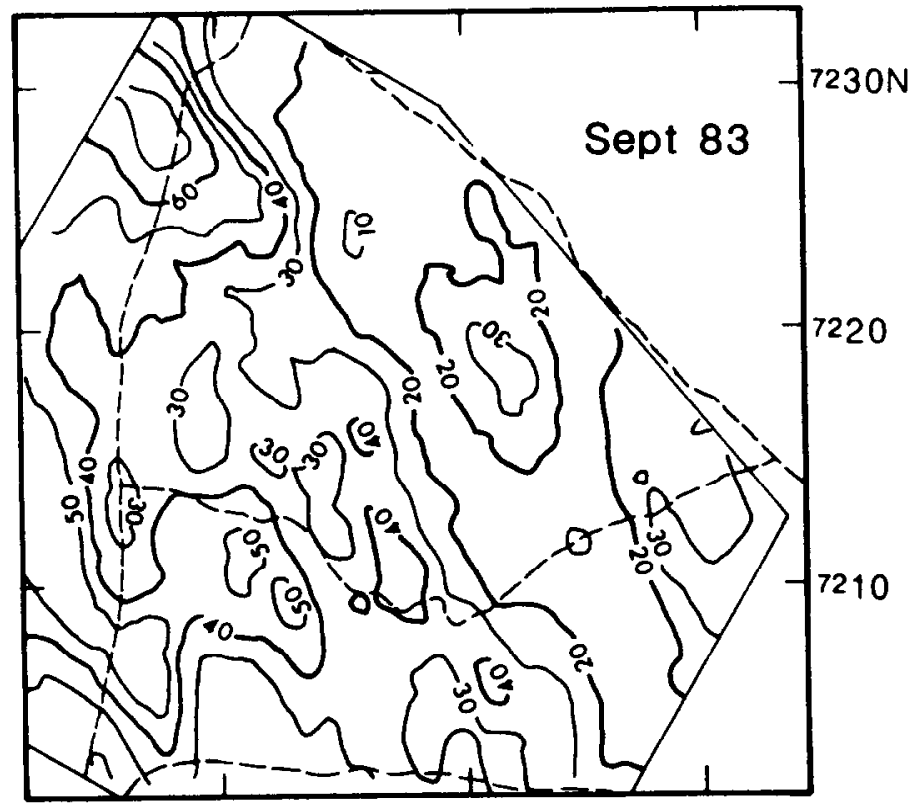

Fig. 5. Isoline maps of ground cover.

differs from the USLE. The input is the mean seasonal interception of erosive rainfall - a variable which, for grassland, may be determined by mean cover of the ground layer of vegetation. From Zimbabwe data (Elwell and Stocking 1973, 1976), corroborated by experiments in Australia (Lang 1979, Singer et al. 1981), an exponential relationship exists between mean seasonal interception and soil loss. This is presented in Figure 7 where erosion is given as a 'soil loss ratio' which expresses the proportion of soil loss from a vegetation having an interception, $\mathrm{i}$, compared to soil loss from bare fallow. The curve (Fig. 7) represents the sum effect of vegetation in reducing erosion, principally through interception of rainfall, but also through greater infiltration, surface detention of runoff, increased cycling of organic matter, and possibly other less-well-known effects. However, all these effects are summarized in the 1 variable, $i$, which is translated in Figure 7 to a 'soil loss ratio', $C$. The vital importance of establishing good cover is well

demonstrated: at least $30 \%$ mean cover or rainfall interception to achieve acceptably small soil losses.

The Bare Soil Sub-model, K (Table 1 and Figure 6), takes into account the important interaction under tropical conditions of rainfall energy and the erodibility characteristics of the soil. Values for rainfall energy come from locally established relationships between energy and mean annual rainfall (Elwell and Stocking 1975), while soil erodibility is an index value which not only takes into account intrinsic soil properties but also the way that erodibility characteristics change with land use (Elwell 1978). For the purposes of this study, mean annual rainfall figures and observations on soil type and character provide the main input for $K$, which were then related to established values from nearby $\mathrm{Zim}$ babwe for verification.

The topographical Sub-model, $X$, uses the length and degree of slope as in the Universal Soil Loss Equation. Because rangeland 


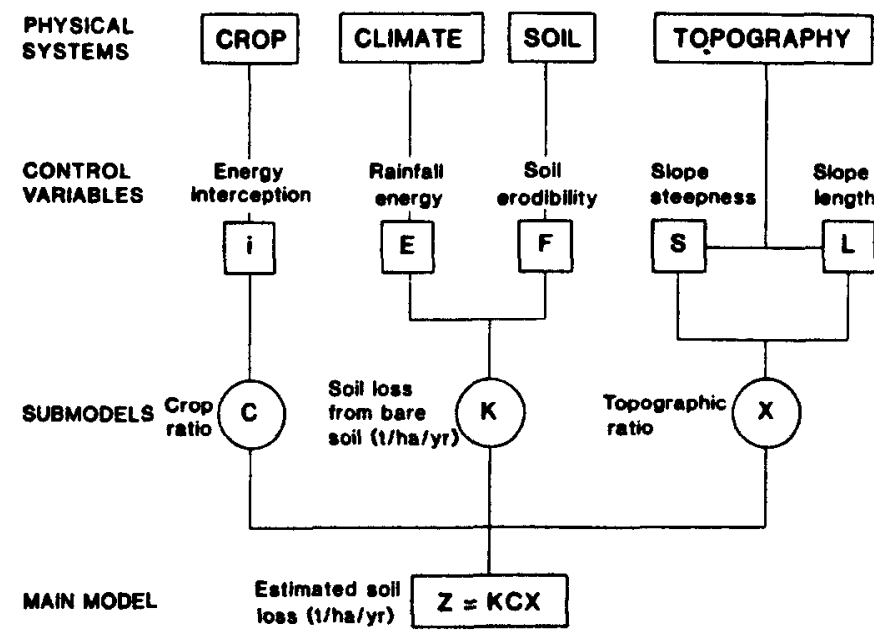

Fis. 6. Structure of the SLEMSA soil loss prediction model (after Elwell and Stocking 1982).

Table 1. Variables in SLEMSA (Soll Lon Estimation Model for Southern Africa).

\begin{tabular}{|c|c|c|c|}
\hline Symbol & Explanation & Units & Derivation \\
\hline \multicolumn{4}{|c|}{ Control variables } \\
\hline $\mathbf{E}$ & Seasonal rainfall energy & Joules $/ \mathbf{m}^{2}$ & $\begin{array}{l}\text { reltionship of energy to } \\
\text { mean annual rainfall }\end{array}$ \\
\hline $\mathbf{F}$ & Soil erodibility & - & $\begin{array}{l}\text { index of soil character- } \\
\text { istics related to known } \\
\text { erodibilities }\end{array}$ \\
\hline $\mathbf{i}$ & Rain energy intercepted & $\%$ & $\begin{array}{l}\text { vegetation cover } \\
\text { measures }\end{array}$ \\
\hline $\mathbf{S}$ & Slope steepness & $\%$ & contòr crossing method \\
\hline $\mathbf{L}$ & Slope length & metres & standard length taken \\
\hline \multicolumn{4}{|c|}{ Submodels } \\
\hline $\mathbf{K}$ & Bare soil condition & tonnes/ha & $\begin{array}{l}\text { design graph linking } \\
\mathrm{E} \& \mathrm{~F}\end{array}$ \\
\hline $\mathbf{C}$ & Canopy cover & - & $\begin{array}{l}\text { soil loss ratio related to } \\
\text { i }\end{array}$ \\
\hline $\mathbf{X}$ & Topography & - & $\begin{array}{l}\text { soil loss ratio linking } \\
\text { S \& L }\end{array}$ \\
\hline \multicolumn{4}{|c|}{ Main model } \\
\hline $\mathbf{Z}$ & $\begin{array}{l}\text { Predicted mean annual } \\
\text { soil loss }\end{array}$ & tonnes/ha & $\mathbf{Z}=\mathbf{K} \cdot \mathbf{C} \cdot \mathbf{X}$ \\
\hline
\end{tabular}

has very variable length of slope and both USLE and SLEMSA were originally designed for cropland, it is not justifiable to take slopes longer than about $\mathbf{1 0 0}$ metres. For this study it was decided to adopt a uniform slope length of $\mathbf{3 0}$ metres, which corresponds to the standard erosion and soil loss plots used in southern Africa. Estimates of soil loss will, therefore, strictly be the field rate of soil loss" or 'gross erosion' or the rate that would have occurred if a bounded field plot had been established at that site. This is important to note because rates of erosion depend on scale-a point to which we shall return when discussing net erosion and sediment yield. The input into $X$ of degree of slope comes from the mean slope angle in each kilometre grid cell, a value obtained by counting contour crossings of the 1:50,000 topographical map (see Stocking 1972 for method).

The variables for operating SLEMSA are summarized in Table. 1.

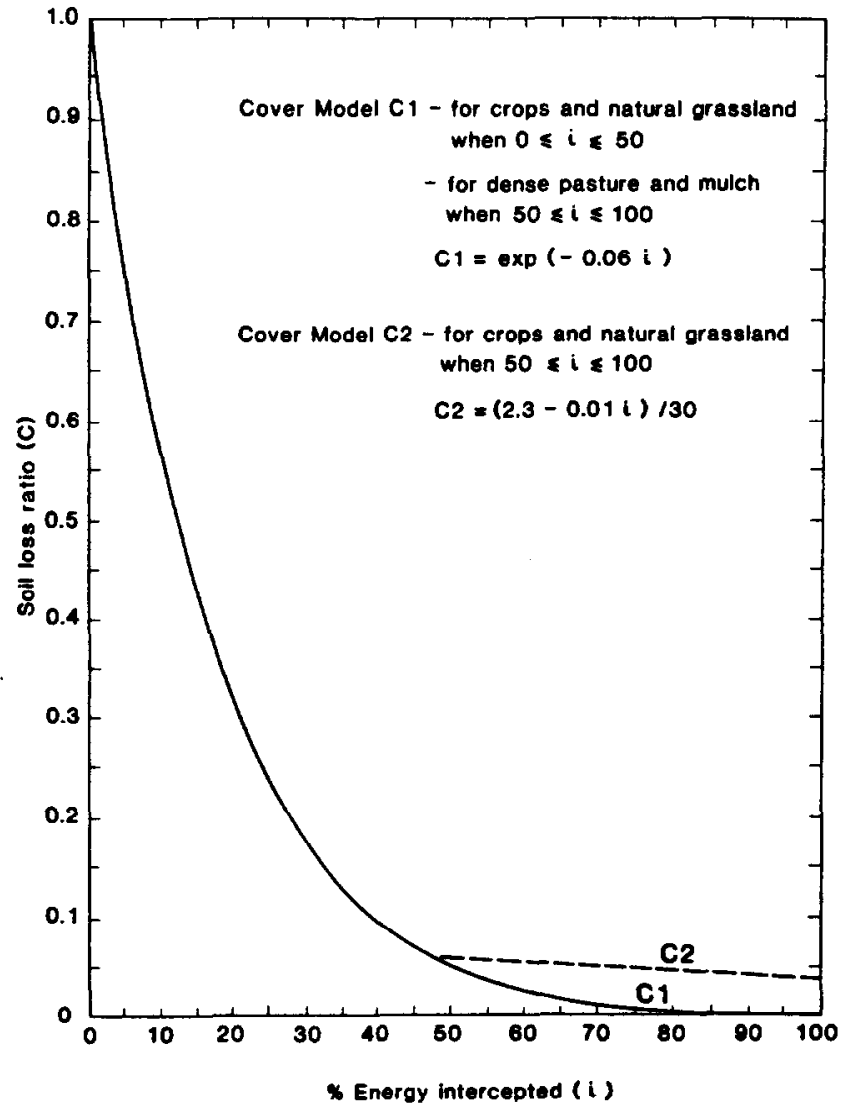

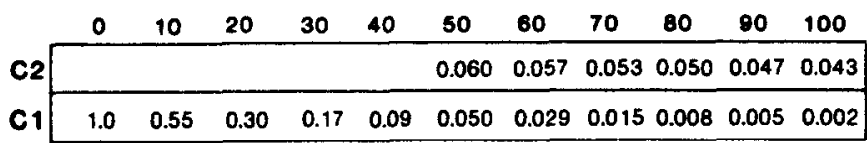

Fig. 7. Vegetation cover sub-model of SLEMSA.

\section{Data Analysis and Calculations}

The control variables for operating SLEMSA in the study area in Botswana were either effectively uniform for the whole area or were abstracted for each kilometre grid cell.

Seasonal rainfall energy was calculated on the basis of a mean annual rainfall of $550 \mathrm{~mm}$, giving a mean energy of 10,000 joules $/ \mathrm{m}^{2}$. This was derived from the established relationship between mean annual rainfall and seasonal energy for stations having intense rain and thunderstorms (Stocking 1981), which is substantiated by van der Poel (1980) in Botswana. The seasonal energy was taken to be uniform over the whole study area.

Soil erodibility was the most difficult variable to estimate without direct experiments. In Zimbabwe, Regosols are normally taken to have an erodibility rating, F-value, of 4 , while Luvisols with a sand or loamy sand texture also have a rating of 4 . In effect, this describes them as being fairly erodible, mainly through the development of surface crusts which reduce infiltration and increase surface runoff. The Botswanan soils are more stony and shallow. Experience suggests they are somewhat less erodible than Regosols in Zimbabwe when under rangeland. With present information there is no effective difference in erodibility between the granite and dolomite-derived soils, and both are therefore rated throughout the study area as 4.5 .

Rainfall interception or, in the case of this study, the cover of the ground layer vegetation, was, for convenience, taken from the isoline maps of grass cover (Fig. 5), although it could have been taken directly from estimates made during the kriging process. Three surveys were available for different parts of the year, each 


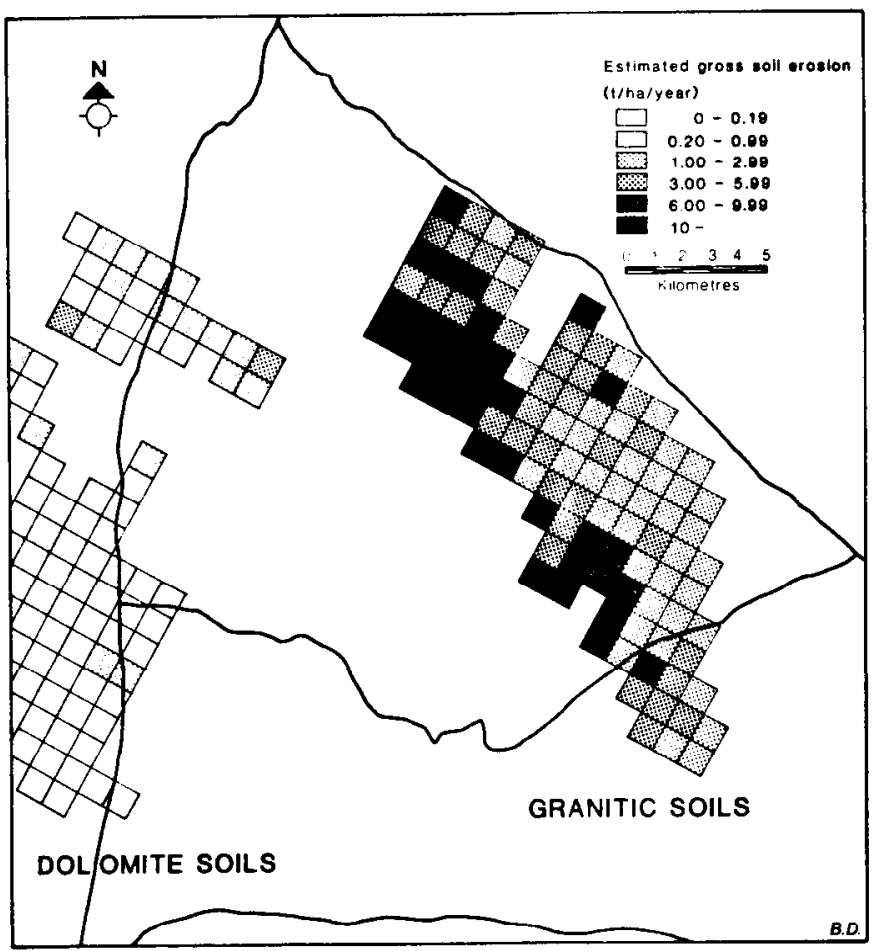

Fig. 8. Estimated gross rates of soil erosion from granites and from dolomite.

giving a separate distribution map of cover: January, May, and September 1983. The basic pattern of ground layer cover in the area is determined edaphically (Abcl et al. 1987), but this is much modified by grazing. The September cover represents the state of the vegetation at the end of the dry season just prior to the early season rains (1983 was used in the absence of data for September 1982). January gives the cover half way through the rainy season, and May at the end of the rains. There was no consistent pattern of increase in cover through the growing season because of utilization of the range, yet there were some significant differences in vegetation cover between sites and between the survey times. To obtain an estimate of the mean seasonal rainfall interception, the 3 cover values for each kilometre square were averaged, and it is this mean cover value that was put into SLEMSA.

Slope steepness was determined by the method described aboye from 1:50,000 maps of the study area. Wentworth's Method (Wentworth 1940) gives slope in degrees, which was then converted to percent. Slope length was taken as a standard $30 \mathrm{~m}$ (see above).

Bare Soil Submodel, $K$ was based on the design graph used in Zimbabwe (Elwell 1978). The values are derived empirically:

$$
\mathrm{K}=\exp [(0.461+0.7663 \mathrm{~F}) \ln \mathrm{E}+2.884-(8.1209 \mathrm{~F})]
$$

where $K$ is the soil loss from bare fallow conditions

$E$ is the rainfall energy in joules $/ \mathrm{m}^{2}$

$F$ is the erodibility rating

Canopy Cover Submodel, $C$ converts the bare soil prediction from the $\mathrm{K}$-submodel to a prediction for an area with a vegetation cover:

$$
\mathrm{C}=\exp (-0.06 \mathrm{i})
$$

where $\mathrm{C}$ is the ratio of soil loss from a crop having an interception value of $i$, compared to soil loss from bare fallow

$i$ is the percent energy intercepted (or mean cover).

Topographic Submodel, $X$ further converts the bare soil sub- model to take into account the influence of slope. American research (Wischmeier and Smith 1978) was adapted to give a more realistic standard slope of $4.5 \%$ and $30 \mathrm{~m}$ :

$$
X=L^{0.5}\left[0.76+0.53 \mathrm{~S}+0.076 \mathrm{~S}^{2}\right] / 25.65
$$

where $\mathrm{X}$ is the ratio of soil loss from standard conditions

$\mathrm{L}$ is slope length, metres

$S$ is slope steepness, percent

The analyses and final calculation of the Main Model to give the predicted soil loss in each grid cell of 1 kilometre square was done using Minitab, an interactive statistical package (Ryan et al. 1985).

\section{Results and Discussion}

Figure 8 shows the final map of gross erosion from the 2 contrasting areas of rangeland in Botswana. On the granite soils erosion rates vary from about 1 to 12 tonnes / ha / year, while on the dolomite soils they are considerably less. The difference between the 2 is accounted for primarily by cover. From our field experience the method seems to be identifying real differences in rates of erosion between different landscape units. The best corroboration as to the absolute rates of erosion that are predicted comes from a series of experiments conducted between 1952 and 1962 at Matopos Experiment Station near Bulawayo in Zimbabwe on a sandy soil in a climate only slightly wetter than in Botswana (Barnes and Franklin 1970, Elwell and Stocking 1973). On almost bare soil and a $4 \%$ slope, mean annual soil loss over 9 years was nearly 11 tonnes/ha. Where the rangeland was ungrazed erosion was less than 1 tonne, and intermediate values occurred for other treatments. We feel therefore that the use of vegetation cover survey, kriging, and a simple soil loss model gives figures for rangeland erosion that are both explicable and of approximately the right magnitude.

These values for erosion are the rate that would have occurred if a bounded 30 metre long plot had been established on the average slope and the mean cover condition of each kilometre grid square. This is important in relation to any attempt to use these results to compute sediment yields into the river systems and out of the catchment areas. The contribution of any part of a catchment to sediment yield is the difference between gross erosion (or the field rate of erosion) as estimated in this study and the deposition of sediments. This deposition occurs on all segments of slope as any 1 eroded particle moves down the catchment in a series of storm 'flushes' or jumps. On a small bounded plot only 1 such 'flush' or storm would be required to record that particle as having been eroded, but in a whole catchment many storms might be needed for that particle to leave the catchment. This is why estimates of sediment yield based solely on the areal extrapolation of field rates of erosion grossly overestimate the real situation.

Finally, it is interesting to estimate sediment yield from the 2 catchments in order to gain an idea of the total removal of material from the landscape. At the present state of knowledge and the development of techniques, the only viable method of converting gross erosion to sediment yield is to apply a 'Sediment Delivery Ratio' computed from a knowledge of catchment size, shape, and assumed efficiency in passing sediment. We have used a ratio of $27 \%$ based on data from a number of streams in the USA from environments which are not too dissimilar from semiarid Botswana (Task Committee on Sedimentation 1970). This gives 1.4 tonnes / ha / yr from the granite catchments and nil for the dolomite because no streams issue from this area.

\section{Literature Cited}

Abel, N.O.J., Flint, M.E.S., Hunter, N.D., Chandler, D., and Maka, G. 1987. Cattle-keeping, ecological change and communal management in Ngwaketse. Vol. II: Main Report. Overseas Development Group, Univ. of East Anglia/Integrated Farming Pilot Project, Ministry of Agriculture, Gaberone/International Livestock Commission for Africa, Addis Ababa. 
Barnes, D.L., and M.J. Franklin. 1970. Runoff and soil loss on a sandveld in Rhodesia. Proc. Grassld. Soc. So. Afr. 5:140-144.

Curran, P.J. 1983. Problems in the remote sensing of vegetative canopies for biomass estimation. P. 84-100. In: R.M. Fuller (ed.), Ecological Mapping from Ground, Air and Space. Proc. Symp. at Merlewood Exp. Sta., November 1981, ITE Symp. No. 10, NERC, Swindon.

Dancy, K.J., R. Webster, and N.O.J. Abel. 1986. Mapping grass cover and biomass in Botswana by kriging from low-level aerial photographic sampling. Inter. J. Remote Sensing 7:1679-1704.

Elwell, H.A. 1978. Soil loss estimation: compiled works of the Rhodesian multi-disciplinary team on soil loss estimation. Instit. Agr. Eng., Harare, Zimbabwe.

Elwell, H.A., and S. Gardner. 1975. Comparison of two techniques for measuring percent canopy cover of row crops in erosion research programmes. Res. Bull, 19, Dep. Conserv. and Extension, Zimbabwe.

Elwell, H.A., and M.A. Stocking. 1973. Rainfall parameters and a cover model to predict runoff and soil loss from grazing trials in the Rhodesian sandveld. Proc. Grassld. Soc. So. Afr. 9:157-163.

Elwell, H.A., and M.A. Stocking. 1975. Parameters for estimating annual runoff and soil loss from agricultural lands in Rhodesia. Wat. Resour. Res. 11:601-605.

Elwell, H.A., and M.A. Stocking. 1976. Vegetal cover to estimate soil erosion hazrd in Rhodesia. Geoderma 15:61-70.

Elwell, H.A., and M.A. Stocking. 1982. Developing a simple yet practical method of soil loss estimation. Tropical Agr. (Trinidad) 59:43-48.

Evans, R.A., and R.M. Love. 1957. The step point method of sampling-a practical tool in range research. J. Range Manage. 10:208-212.

Lang, R.D. 1979. The effect of ground cover on surface runoff from experimental plots. J. Soil Conserv. N.S.W. 35:108-114.

Penning De Vries, F.W.T., and M.A. Djiteye (eds.) 1982. La Productivite des Paturages Saheliens. Centre for Agricultural Publishing and Documentation, Wageningen.

Pratt, D.J., and M.D. Gwynne (eds.) 1977. Rangeland ecology and management in East Africa. Hodder and Stoughton, London.

Prince, S.D., and W.L. Astle. 1986. Satellite remote sensing of rangelands in Botswana. I. Landsat MSS and herbaceous vegetation. Int. J. Remote Sensing.

Prince, S.D., and C.J. Tucker. 1986. Satellite remote sensing of rangelands in Botswana. II. NOAA AVHRR and herbaceous vegetation. Int. J. Remote Sensing (in press).
Richardson, A.J., and C.L. Wlegand. 1977. Distinguishing vegetation from the soil background information. Photogram. Eng. \& Remote Sensing 43:1541-1552.

Ryan, B.F., B.L. Joiner and T.A. Ryan. 1985. Minitab handbook. Second Edition. Duxbury Press, Boston.

Sampson, J.R. 1978. The Surface II graphics program (Revision One). No. 1 Series on Spatial Analysis, Kansas Geolog. Surv., Lawrence.

Short, N.M. 1982. Landsat tutorial workbook. NASA, Washington D.C.

Singer, M.J., P.H. Walker, J. Hutka, and P. Green 1981. Soil erosion under simulated rainfall and runoff at varying cover levels. Div. Soils Rep. No. 55, Commonwealth Sci. and Industr. Res. Organiz., Canberra.

Stocking, M.A. 1972. Relief analysis and soil erosion in Rhodesia using multi-variate techniques. Zeitschrift fur Geomorphologie 1616:432-443.

Stocking, M.A. 1981. A working model for the estimation of soil loss suitable for underdeveloped countries. Development Studies Occas. Pap. No. 15, Univ. East Anglia.

Stocking, M.A. and H.A. Elwell. 1976. Vegetation and erosion: a review. Scottish Geogr. Mag. 92:4-16.

Task Committee on' Sedimentation 1970. Chapter IV. Sediment sources and sediment yields. J. Hydraul. Div. A.S.C.E. 96(HY6):1283:1329.

Tucker, C.J., C. Van Praet, E. Boerwinkel, E. Gaston, and A. Gaston. 1983. Satellite remote sensing of total dry matter production in the Senegalese Sahel. Remote Sensing of Environment 13:461-474.

Van der Poel, P. 1980. Rainfall erosivity and its use for soil loss estimation. Ministry of Agr., Government Printer, Gaberone, Botswana.

Vossen, P., D.D. Dambe, and K.A. Molimi. 1985. Agrometeorological survey of the Integrated Farming Pilot Project (IFPP) of Pelotsheltha. IFPP, Dep. Agr. Field Serv., Ministry of Agr. and Dep. Meteorol. Serv., Gaberone, Botswana.

Webster, R.1985. Quantitative spatial analysis of soil in the field. Advances in Soil Sci. 3:2-70.

Wendelaar, F.E. 1978. Applying the Universal Soil Loss Equation in Rhodesia. Soil and Water Eng. Sec., Instit. Agr. Eng., Harare, Zimbabwe.

Wentworth, C.K. 1940. A simplified method of determining the average slope of land surfaces. Amer. J. Sci. 5:20.

Wischmeier, W.H., and D.D. Smith. 1978. Predicting rainfall erosion losses-a guide to conservation planning. USDA Handbook 537, Washington, D.C.

\section{Does your range library have these?}

35-Year Index, Journal of Range Management, edited by Elbert H. Reid.
$\$ 10.00$

Plants That Poison, by E.M Schmutz and L.B. Hamilton. $\$ 9.95$

Trail Boss Cowboy Cookbook, $\$ 13.00$

Range Research: Basic Problems and Techniques, edited by C. Wayne Cook and James Stubbendieck. $\$ 28.00$

Rangeland Plant Physiology, edited by Ronald E. Sosebee. $\$ 14.50$

Special Management Needs of Alpine Ecosystems, edited by Douglas A. Johnson. $\$ 4.50$

Rangeland Hydrology, by F.A. Branson, G.F. Gifford, K.G. Renard, and R.F. Hadley. $\$ 15.00$

All prices quoted are postpaid. Also available are back issues of Journal of Range Management and Rangelands and some proceedings and symposia. Place orders and ask for a complete list of publications available from Society for Range Management, 1839 York St., Denver, Colorado 80206. (303) 355-7070. 